\section{THE INDIAN TOTAL ECLIPSE}

THE 37 th volume of the memoirs of the Royal Astronomical Society, containing Major Tennant's report on the total eclipse of the sun of August I7th and r8th, r 868 , has just been issued, and we are enabled, by the courtesy of the Council of the Society, to lay an illustrated notice of it hefore nur readers, was fully provided with the means of photographing the eclipse as well as of determining by means of the spectroscope the nature of the spectrum of the promi nences and of the corona. In our notice we may pass over the preface and the narrative of operations which includes the astronomical determination of the position of the observatory, and come to the spectroscopic observations.

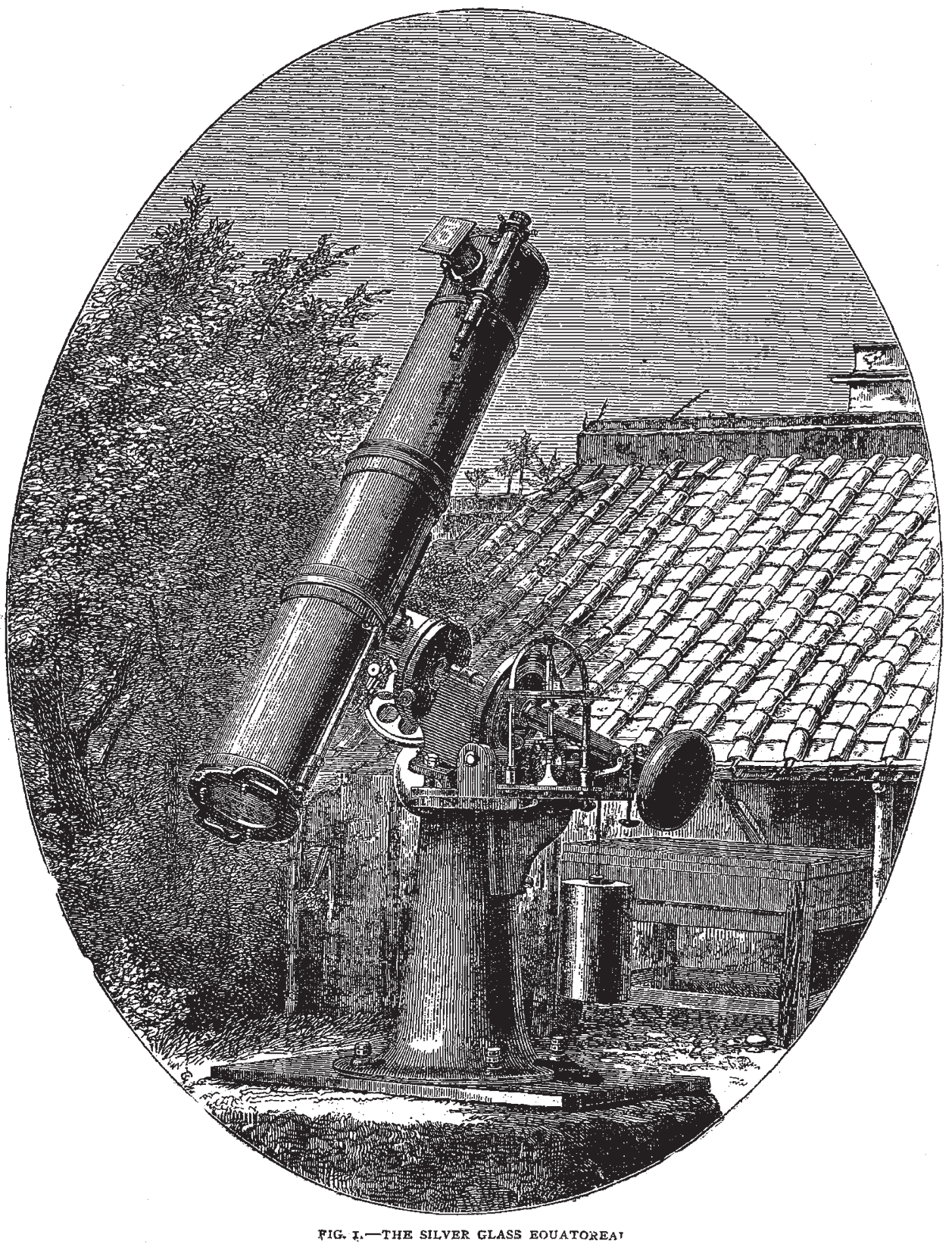

The Indian eclipse was a notable one in the history of astronomy, for as the eclipse of 1860 endorsed the notion that the prominences were solar, so that of 1868 set at rest the gaseous nature of the red flames or red protuberances - so that we have two successive eclipses "settling" two important problems.

Thanks to the care of Mr. De la Rue, Major Tennant
We first have the spectrum of the corona. Major Tennant writes :-

Directly I saw the whole moon in the finder I set the crosswires immediately outside its upper limb. By the time I got to the spectroscope, the cloudy range, seen in the photographs, had vanished from the slit, and I saw a very taint continuous spectrum. Thinking that want of light prevented my seeing the 
bright lines, which I had fully expected to see in the lower strata of the corona, I opened the jaws of the slit, and repeatedly adjusted by the finder, but without effect. What I saze was undoubtedly a continuous spectrum, and I saze no lines. ${ }^{*}$ There may have been dark lines, of course, but with so faint a spectrum and the jaws of the slit wide apart, they might escape notice.

We next have the spectrum of the Great Horn :-

One line in the red was so beautiful that it needed an effort to turn my attention to anything else; there was a line in the orange not so well defined, and one in the green which seemed of the green line coincides with that of the brightest line in $b$, instead of the mean of the three, which I read as a verification; the line near to $\mathrm{F}$ was in all probability $\mathrm{F}$ itself; $\mathbf{E}$ was certainly not seen by me. The line in the blue it is useless from my data to speculate upon, $I$ must hope that some one else has identified it.

It is pleasing to point out how very nearly Major Tennant's observations, as now given, approximate to the true state of the case, which we can now determine any day that the sun shines. He must be entirely congratulated

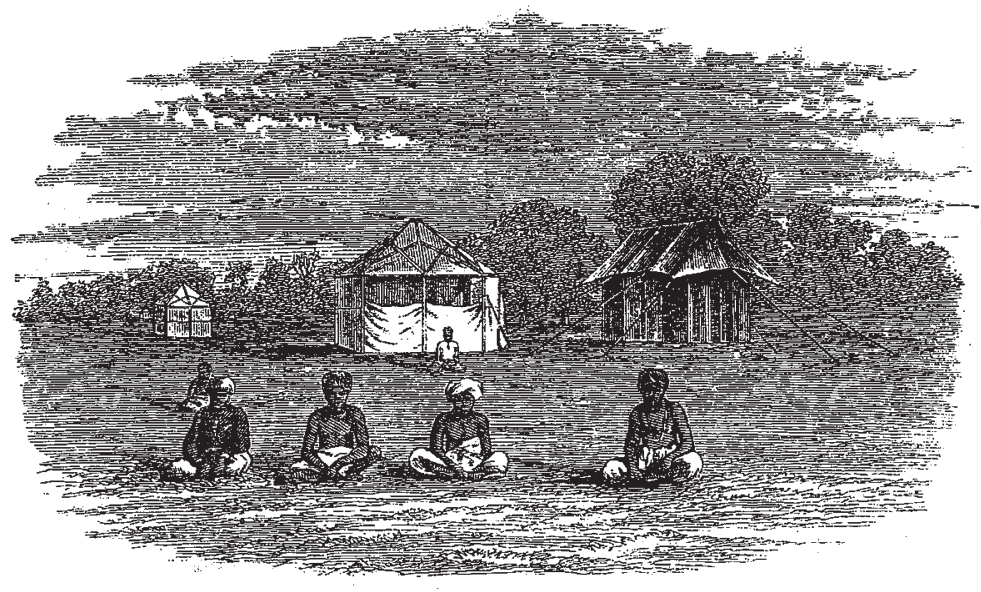

FIG. 2,-OBSERVATORY TENTS

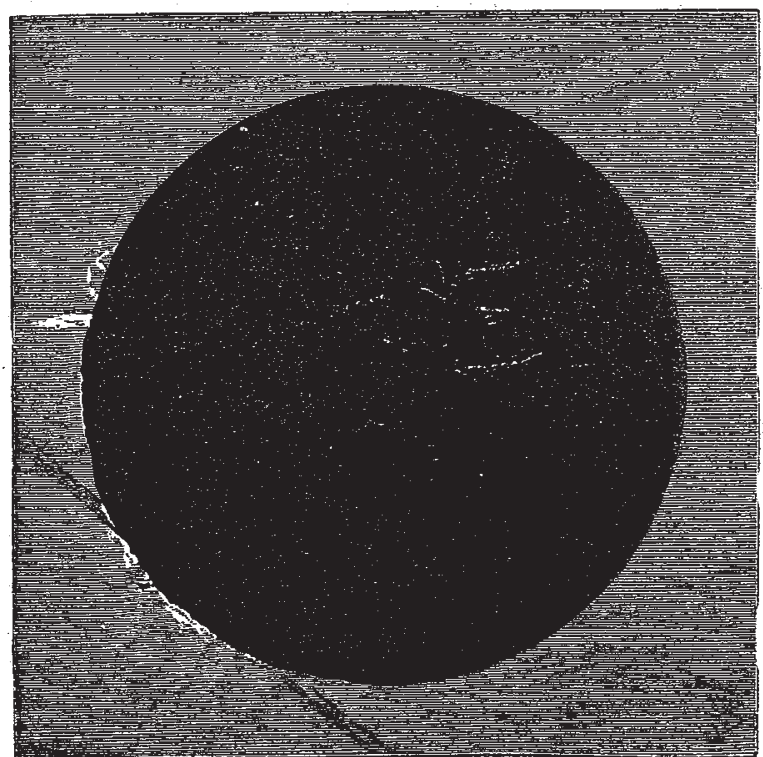
FIG. 3-ONE OF THE FIRST PHOTOGRAPHS. SHOWING THE

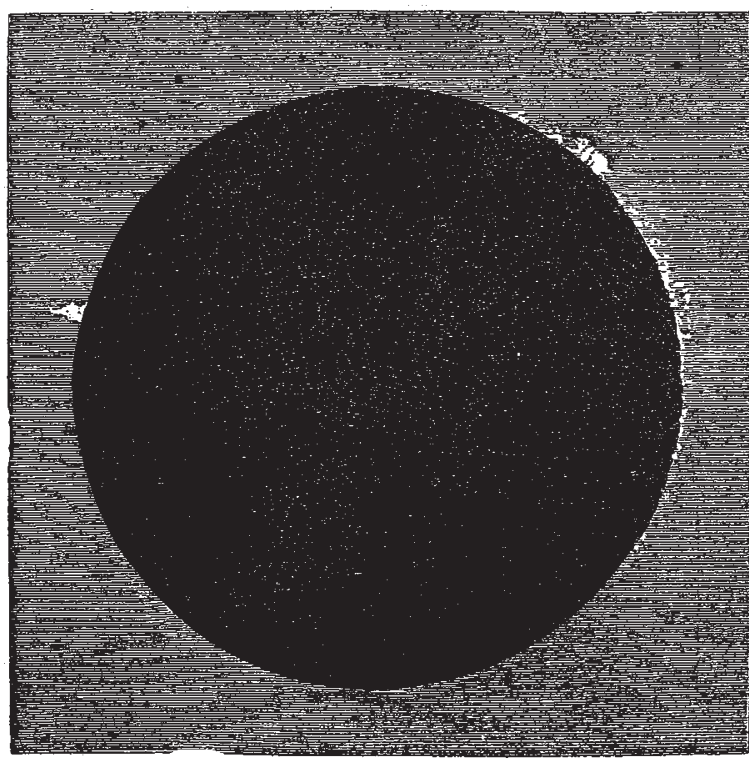

FIG. 4.-THE LAST PHOTOGRAPH TAKEN, SHOWING THE ANIMAL-LIKE PROMINENCE AND THE ECLIPSE OF THE GREAT HORN multiple (it must be remembered that I had not time to adjust the jaws of the slit accurately, and that the brilliancy of these lines made them broader by irradiation); beyond, I saw a line just defined, which, as will be seen from the measures before given, must have been near to $F$, and still further off in the blue I saw a hazy light probably beyond G.

The red and yellow lines were evidently $\mathrm{C}$ and $\mathrm{D}$, the reading

* In the instructions for Lieut. Herschel his attention was first drawn to the protuberances. I therefore had resolved to attend first to the corona, lest each of us should have only the same partial tale. on the degree of success of his spectroscopic observations - observations made, according to his report, under difficulties which he ought not to have encountered. Major Tennant's evidence in favour of the continuous spectrum of the corona has been entirely confirmed by the observations since made in America.

The photogràphic results we may introduce by a woodcut of the observatory and of the instrument, with speculum of nine inches aperture, mounted by Mr. Browning, with which the photographs were taken. 
The most notable phenomenon visible during the Indian eclipse was the Great Horn visible in Fig. 3, the structure of which was extremely curious. Below it in the drawing we have a part of the chromosphere, including a "flaring," which has' been since called a "radiance" by the American astronomers. Fig. 4 was the last photograph taken, and here it is seen that the Great Horn is nearly eclipsed, and that the chromosphere on the opposite side of the sun is now exposed, including a strange animallike form, which much struck the observers. An examination into the structure of the Great Horn is not the least interesting part of the report.

Major Tennant thus sums up his results :-

First.-The corona is the atmosphere of the sun not se'f-luminous, but shining by reflected light. It is evidenced both by the spectroscope and polariscope that this is the case, but there is one reservation to be made. The polariscope has shown clearly that the light of the brightest part of the corona is mainly reflected; but, looking to the flare which is seen in photographs No. 2 and 3 , it seems impossible to doubt that in those places there must have been some inherent luminosity in the corona; unless indeed we consider the flare as a modified form of protuberance. It is, I think, now certain that luminous gas issues from what is more strictly the sun, and I apprehend this flare to be some of this

Secondly. - The Great Horn certainly was composed of incandescent vapours, and probably all the brilliant protuberances are. the same. In the Great Horn these vapours were hydrogen, sodium, and magnesium. It seems to me perfectly certain that the ignited hydrogen issued from the sun itself, and that it carried up with it the light vapours of sodium and magnesium far above the level at which they would naturally lie; hydrogen naturally would be the very highest of the gaseous vapours, and consequently the coolest; if, however, it were set free at the surface of the sun it would be intensely hot, and seek, with great violence, to ascend, in which process, if there be a stratum of heated vapours, such as is usually believed to exist round the sun, the hydrogen would partly displace and carry up these vapours, and the lighter would be taken in preference. In fact, in this case it has carried the two lightest, and that of iron, which is so much heavier ( $I$ think we may presume this. from the absence of the line corresponding to E), was either displaced or dropped sooner than the height at which I observed. Photograph No. I shows that there were two jets of vapour concerned in forming this Horn. One, the largest and most northerly, is seen nearly perpendicularly to the limb, and seems also to have been the most luminous; the other issues about $20,000^{*}$ miles towards the south, and at an angle. They met at a height of some $16,000^{*}$ miles, and the result was the rapid vorticose motion, which is evidenced in all the photographs as having existed in the upper portion. I believe. I have the good fortune to be the first person to recognise such a phenomenon.

I think that gases or vapours issuing quietly from the solar surface would tend locally to raise the superincumbent ignited vapours. In places where they were most abundantly given out the elevation would be greatest, everywhere the gas would leak through in streams, producing occasionally such phenomena as the flare 1 have spoken of in Nos. 2 and 3. For a time the ignited vapour might, I think, form, as it were, a case for the light included gas, which would be to all appearance inflated like the animal figure in No. 6: Soon, however, the slightly coherent casing would be burst and the gaseous contents would issue freely the heavier vapours would, of course, to some extent be carried off by the gas, but would mainly settle down in small masses. Such, I think, is the state depicted in the southern protuberance of No.r.

I would now draw attention to Plate No.I, and the glare and luminous stratum. If that glare be from sunlight, it must, I think, be acknowledged that the remaining ray was but small. The luminous nearly even stratum then is not the sun ; but it is intensely bright, so much so, that nowhere is it lost in the solar glare. Its height is but small (I estimate it at 7,200 miles), and I believe it to be the mass of heavy luminous vapours, to whose elective absorption we owe the Fraunhofer lines in the solar spectrum. At the north end of this stratum near the Great Horn, it is broken into beads of light ; $\dagger$ and $I$ am disposed to think

* These dimensions refer to the projections on a plane perpendicular to the visual ray.

+ This is the same place where Captain Branfill saw beads. these are the veritable Baily's beads, of which I have always felt that the description would be difficult to apply to sunlight ; I nean the statement which has been made of the light being silvery, \&c. If these beads are really phenomena of the absorbing stratum, one can well understand the use of such terms.

In an addendum, in which the author's theory is attempted to be maintained, Major Tennant refers to the work which has been done in this country between the eclipse and the issue of the report. He considers that the sun is surrounded by an atmosphere sufficiently dense to reflect the solar light, but it is not explained why a continuous spectrum and not the solar spectrum is actually reflected; and that the hydrogen is enveloped in a denser atmosphere, resisting its diffusion and expansion, but why the spectrum of this atmosphere is so simple is not explained.

The author concludes by acknowledging the services rendered by Mr. De la Rue in the preparation of the report.

\section{FALL OF A METEORITE}

THE Director of the Meteorological Office has forwarded the following extract from a letter from $M$. Coumbary, Director of the Imperial Meteorological Observatory at Constantinople for publication :-

Constantinople, 9 mars, I87o

Mon cher Monsieur,-Je saisis l'occasion qui m'est offerte pour vous transmettre la communication que vient de nous faire $M$. Carabella, Directeur des Affaires Etrangères du Vilayet de Tripoli de Barbaru.

$$
\text { "Tripoli, } 2 \text { février, } 1870
$$

"Le Mutasserif de Mourzouk (Fezzan), latitude $26^{\circ} \mathrm{N}$., longitude $12^{\circ} \mathrm{E}$. de Paris, nous fait savoir que vers le 25 décembre, i 869 , il est tombé à l'est de la ville, vers le soir, un immense globe de feu, mésurant un mètre à peu près de diamètre, et qu'au moment où il a touché terre il s'en est détaché de fortes étincelles qui, en se produisant, claquaient comme des coups de pistolet, et exhalaient une odeur que l'on n'a pas specifiée. Cet aërolithe est tombé à peu de distance d'un groupe de plusieurs arabes, parmi lesquels se trouvait le Chiok-el-Veled de Mourzouk. Ceux-ci en ont été tellement éffrayés qu'ils ont im. médiatement déchargé leurs fusils sur ce monstre incompréhensible. Son Excellence Ali Riza Pacha a écrit d Mourzoutk pour faire transporter ici l'aërolithe; au cas probable ou il soit trop pesant on le mettra en pièces; nous vouis enverroms tout cela. Il y a un mois de voyage d'ici à Mourzouk. Ce n'est done que dans deux mois à peu près que nous pourrons vous faire cette expédition. S'il peut vous être de quelque intérêt de le savoir, je vous dirai que quelques voyageurs du Waddad que $j$ 'interrogeais m'ont dit que le Sultan du Waddad et tous les grands personnages de sa cour ont des poignards, des sabres et des lances faits avec du fer tombé du ciel, et quili en tombe de grandes quantités dans ce paystlà. (Sd) "L. CARABELCA"

Je crois devoir vous informer qu'au reçu de cette lettre et $z$ la suite des démarches nécessaires, S.A. le Grand. Vizir a bien voulu faire donner ordre immédiatement par téléggraphe à Tripoli, pour que l'on prenne les mesures nécessaires afin que ce météorite nous parvienne intact--Recevez, cher monsieur, \&c.,

$$
\text { (Sd.) ARISTIDe Coumbari }
$$

\section{NOTES}

ON the 5 th of March died at Vienna; Joseph Redtenbacher, Professor of Chemistry at the University. He was born in 1810 , and studied under Eichig, conjointly with whom he published a determination of the atomic weight of carbon, and several other memoirs. His principal merit consists in the discovery of acrolein and acrylic acid. Most of his papers were published between 1839 and 1848 . With his death chemistry in Austria passes entirely into younger hands; his colleague, Professor Schröber, the discoverer of amorphous phosphorus, having lately been nominated Master of the Mint, and replaced in his chair by Illasiwetz. The succession of Redtenbacher will be divided into two parts, and the building of a new laboratory 